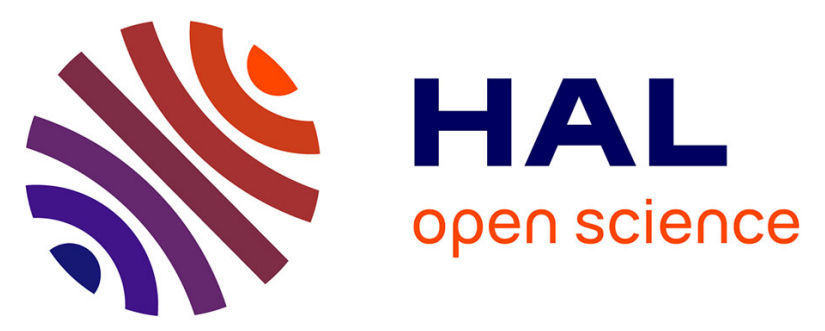

\title{
Dopamine ( DRD 2 ) and Serotonin ( HTR 2A, 2C) Receptor Gene Polymorphisms do not influence early response to Risperidone in South Indian Patients with Schizophrenia
}

Charanraj Goud Alladi, Ravi Philip Rajkumar, Surendiran Adithan, Cynthia

Marie-Claire, Frank Bellivier, Deepak Gopal Shewade

\section{To cite this version:}

Charanraj Goud Alladi, Ravi Philip Rajkumar, Surendiran Adithan, Cynthia Marie-Claire, Frank Bellivier, et al.. Dopamine ( DRD 2 ) and Serotonin ( HTR 2A, 2C) Receptor Gene Polymorphisms do not influence early response to Risperidone in South Indian Patients with Schizophrenia. Fundamental \& Clinical Pharmacology, 2018, 33, pp.355 - 364. 10.1111/fcp.12424 . hal-03032951

\section{HAL Id: hal-03032951 \\ https://hal.science/hal-03032951}

Submitted on 1 Dec 2020

HAL is a multi-disciplinary open access archive for the deposit and dissemination of scientific research documents, whether they are published or not. The documents may come from teaching and research institutions in France or abroad, or from public or private research centers.
L'archive ouverte pluridisciplinaire HAL, est destinée au dépôt et à la diffusion de documents scientifiques de niveau recherche, publiés ou non, émanant des établissements d'enseignement et de recherche français ou étrangers, des laboratoires publics ou privés. 
Article type : Original Article

\title{
Dopamine (DRD2) and Serotonin (HTR2A, 2C) Receptor Gene Polymorphisms do not influence early response to Risperidone in South Indian Patients with Schizophrenia
}

\author{
Charanraj Goud Alladi ${ }^{\text {a,d }}$, Ravi Philip RajKumar ${ }^{\text {b }}$, Surendiran Adithan ${ }^{\text {a }}$, \\ Cynthia Marie-Claire ${ }^{\mathbf{d}}$, Frank Bellivier ${ }^{\text {c,d }}$, Deepak Gopal Shewade ${ }^{\text {a,* }}$
}

${ }^{a}$ Department of Pharmacology, Jawaharlal Institute of Postgraduate Medical Education and Research, Puducherry, India

${ }^{\mathrm{b}}$ Department of Psychiatry, Jawaharlal Institute of Postgraduate Medical Education and Research, Puducherry, India

${ }^{c}$ Inserm, U1144, Paris F-75006, France; Université Sorbonne Paris Cité, UMR-S 1144, Paris F-75006, France; AP-HP, GH Saint-Louis - Lariboisière - F. Widal, Pôle de Psychiatrie et de Médecine Addictologique, 75475 Paris cedex 10, France; Fondation FondaMental, Créteil, 94000, France.

dInserm, U1144, Paris F-75006, France; Université Sorbonne Paris Cité, UMR-S 1144, Paris F-75006, France.

\author{
*Corresponding Author: \\ Dr. Deepak Gopal Shewade \\ Professor \\ Department of Pharmacology \\ dgshewade@gmail.com \\ Ph: +919442273741 \\ JIPMER, \\ Puducherry-605006, India
}

This article has been accepted for publication and undergone full peer review but has not been through the copyediting, typesetting, pagination and proofreading process, which may lead to differences between this version and the Version of Record. Please cite this article as doi: $10.1111 /$ fcp. 12424

This article is protected by copyright. All rights reserved. 


\section{ABSTRACT}

Treatment response to antipsychotic drugs is variable and conflicting results have been obtained while studying the influence of $D R D 2$ and $H T R 2$ genetic variants on antipsychotic drug efficacy. To explore further, the present study aimed to assess the influence of DRD2 -141 C Ins/Del, Taq1A and HTR2A $1438 \mathrm{G} / \mathrm{A}, 102 \mathrm{~T} / \mathrm{C}$ and $H T R 2 C-759 \mathrm{C} / \mathrm{T}$ genetic polymorphisms in response to risperidone in patients with schizophrenia. The study was conducted among the $n=320$ South Indian patients with schizophrenia who received risperidone treatment (4-8 $\mathrm{mg}$ per day) for a minimum of four weeks. Genotyping was done by real-time PCR. Antipsychotic response was assessed using CGI-I score in cross-sectional group, PANSS score in prospective group at baseline and after receiving the risperidone therapy. DRD2 -141 C Ins/Del (n=310, Ins/Ins=177, Ins/Del+ Del/Del=133, OR 0.70, 95\% CI 0.4-1.2 $p$ 0.2), Taq1A (n=320, AA=35, AG=132, GG=153, $p$ 0.2), HTR2A -1438 G/A (n=320, $\mathrm{AA}=39, \mathrm{AG}=164, \mathrm{GG}=117, p$ 0.2), HTR2A 102T/C $(\mathrm{n}=320, \mathrm{CC}=115, \mathrm{CT}=165, \mathrm{TT}=40, p$ 0.1) HTR2C $-759 \mathrm{C} / \mathrm{T}$ (females $\mathrm{n}=132, \mathrm{CC}=65, \mathrm{CT}+\mathrm{TT}=67$, OR 1.3, 95\% CI 0.6-2.8, $p$ 0.5; males $\mathrm{n}=186, \mathrm{C}=120$, $\mathrm{T}=66$, OR $1.2,95 \%$ CI $0.6-2.4, p$ 0.4) genetic polymorphisms did not show any association with antipsychotic response to risperidone. DRD2 -141 C Ins/Del, Taq1A, HTR2A -1438 G/A, 102T/C and $H T R 2 C-759 \mathrm{C} / \mathrm{T}$ genetic variants are not associated with antipsychotic response to risperidone.

Key words: $\quad$ Risperidone, Schizophrenia, Dopamine, Serotonin, Genetic Polymorphism

This article is protected by copyright. All rights reserved. 


\section{INTRODUCTION}

Schizophrenia (SCZ) a severe psychotic illness requires long term therapy with antipsychotics. Atypical antipsychotics (AAP) act by binding to dopamine (DRD2) and serotonin (5HT) receptors [1]. Clinical efficacy of AAP is highly correlated with potent binding affinity to DRD2 and 5HT receptors [2]. However, a high level of response variability to antipsychotic treatment has been described with regard to acute response, relapse prevention, and side effects. In particular, for the treatment of an acute phase, it is estimated that at least $30-40 \%$ of the patients do not respond to the treatment $[3,4]$. There are no biological markers available to predict therapeutic response and tolerance, thereby leading to lengthy empirical trials with an uncertain outcome. Genetic variation may play a role in AAP response variability and several lines of evidence suggest that polymorphisms within genes coding for proteins implicated in the dopamine and serotonin neurotransmission may influence the AAP efficacy in SCZ [5,6]. In this context, several pharmacogenetic studies have been performed to investigate the implication of dopaminergic and serotonergic candidate genes in AAP response [7]. In particular, polymorphisms in $D R D 2, H T R 2 A$ and to a lesser extent in $H T R 2 C$ genes have been extensively studied in relation with AAP response in SCZ [8,9]. Several studies have shown that the $-141 \mathrm{C}$ Ins/Del and the Taq1A polymorphisms of the DRD2 gene may be associated with a reduced receptor density which may alter the therapeutic response [10,11]. Previous study reports showed that Ins allele carriers of $-141 \mathrm{C}$ Ins/Del polymorphism and A1 allele carriers of Taq1A polymorphism of $D R D 2$ gene have a better therapeutic response $[12,13]$. The association between AAP response and DRD2 Ins/Del polymorphism was also suggested by two meta-analyses $[14,15]$. However, this association was not replicated in a large study with a prospective evaluation of the response [16]. With regard to DRD2 Taq1A polymorphism, no association between this polymorphism and AAP response was suggested by a meta-analysis of seven positive studies and five negative studies [15]. Two additional negative studies were published following this previously mentioned meta-analysis [16,17]. Overall, the interpretation of these conflicting results remains difficult due to allelic heterogeneity related to ethnic background. In particular, some authors report an association between A1 allele and some A2 alleles with good response $[18,19]$.

This article is protected by copyright. All rights reserved. 
With regard to the HTR2A gene, several lines of evidences suggest the implication that this gene in AAP response variability in SCZ. Indeed, it has been shown that the $-1438 \mathrm{G}>\mathrm{A}$ polymorphism in $H T R 2 A$ influences the transcription levels [20]. In addition, previous studies also showed that the T102C polymorphism of this gene plays an important role in $H T 2 R A$ mediated neurotransmission [21,22]. In connection with therapeutic response, 12 studies analysing the influence of T102C polymorphism of the $H T R 2 A$ gene on AAP response have been published: one reports an association between the $\mathrm{C}$ allele and better response [23], another reports an association between $\mathrm{T}$ allele and better response [24], and ten studies did not show any association [25-34]. Six studies investigated $1438 \mathrm{G}>\mathrm{A}$ polymorphism, with two reporting an association between $\mathrm{G}$ allele and poor treatment response [35,36], one reporting that the presence of $\mathrm{G}$ allele was associated with better response [37], another reporting an association between the AA genotype and negative symptoms improvement [38], and two studies not showing any association with response to AAP [31,39]. Of particular interest for the present work, two independent studies among Indian populations, which reported an association between the HTR2A gene (-1438G>A; T102C polymorphisms) and SCZ [40,41]. Among the eight studies that have investigated the role of $H T R 2 C$ gene polymorphism on AAP response, only two have shown an association with AAP treatment response [34,42-48]. HTR2C-759C $>\mathrm{T}$ is an important genetic polymorphism and reported to affect the its receptor expression [49]. Though two studies have been conducted to evaluate the role of $H T R 2 C-759 \mathrm{C}>\mathrm{T}$ in AAP response, they contradict each other, with one study showing no association with response and another study showed an association with improvement in negative symptoms [34,47].

There are several possible reasons for these conflicting results including AAP treatment heterogeneity, ethnic background disparities, treatment duration, response assessment tools, power of detection (sample size) and outcome criteria as well as the study design (prospective or retrospective assessment of the response). So far, the influence of these polymorphisms on AAP response has not been investigated in South Indian populations, except for one study that analyzed the influence of DRD2 Taq1A polymorphism on AAP response and another study that investigated the DRD2 Taq1A

This article is protected by copyright. All rights reserved. 
and HTR2A (-1438A>G;T102C) polymorphisms with risperidone response among the North-Indian population $[50,51]$.

To further explore the association between $D R D 2, H T R 2 A$ and $H T R 2 C$ genes polymorphisms and AAP response to antipsychotic medication, we conducted an association study between these candidate genes and treatment response in South Indian populations of patients with schizophrenia treated with risperidone ( $4-8 \mathrm{mg} /$ day $)$.

\section{METHODS}

Patients with schizophrenia $(n=320)$ recruited for the study as per Diagnostic and Statistical Manual for Mental Disorders-V, criteria were recruited for the study from the Department of Psychiatry, Jawaharlal Institute of Post graduate Medical Education and Research (JIPMER), Puducherry, India. All the patients were recruited between December 2013 and August 2015. The study protocol was approved by Institute Ethics Committee (Project No. JIP/IEC/4/2013/189) and after explaining the study procedure, written informed consent was obtained from all the patients or patients' legally acceptable representatives. A total of 320 patients with schizophrenia were recruited for the study. Among the total patients $n=211$ patients were recruited cross-sectionally, by assessing the clinical global impression improvement (CGI-I) score for antipsychotic response after receiving the risperidone (4-8mg/day) for minimum of 4 weeks and $n=109$ patients were recruited with prospective assessment. In the prospective study group, patients who have not received any antipsychotic medication for past 30 days and have been prescribed risperidone $(4-8 \mathrm{mg} /$ day $)$ as their antipsychotic therapy for a minimum of four weeks were recruited for the study. In the prospective group, baseline characteristics, positive, negative and general psychopathology symptoms were assessed using Positive and Negative Syndrome Scale (PANSS) score before starting the therapy and after receiving the risperidone therapy for a minimum of four weeks. Patients who had history of other medical illness, substance abuse, pregnant women, nursing women and patients with age of $<18$ years were excluded from the study.

This article is protected by copyright. All rights reserved. 


\section{Response Assessment}

In the cross-sectional study group, clinical global impression-improvement (CGI-I) score of sevenpoint rating scale was assessed. After adequate trial of risperidone treatment patients with CGI-I score of 1-3 considered as responders and 4-7 considered as non-responders [52].

In the prospective study group, two response assessment criteria were used. The antipsychotic response to risperidone was assessed using PANSS global score to evaluate the early treatment response. A continuous variable " $\triangle$ PANSS" defined difference between baseline PANSS score and follow-up PANSS score was used for assessment of patients. Patients were also categorized as responders (who showed more than $20 \%$ reduction in PANNS score after four weeks of treatment) and non-responders patients who did not show more than 20\% reduction in PANSS score after four weeks of treatment [53].

\section{DNA extraction \& genotyping}

Five millilitre of blood was collected from each patient to study the genetic polymorphisms in dopamine DRD2 (-141 C Ins/Del, Taq 1A) and serotonin [HTR2A (-1438 A/G, $102 \mathrm{C} / \mathrm{T})$, HTR2C $759 \mathrm{C} / \mathrm{T}]$ receptor genes. DNA extraction was done using standard phenol-chloroform method and quantified by NanoDrop ${ }^{\mathrm{TM}}$ (ThermoFisher). Genotyping for genetic polymorphisms were done using real time thermocycler (ABI Prism 7300) with Taqman ${ }^{\circledR}$ SNP probes for DRD2 genes rs1799732 Assay ID: 0150250174, rs1800497 Assay ID: C_7486676_10 and HTR2A rs6311 Assay ID: C__8695278_10, rs6313 Assay ID: C__3042197_1_ and HTR2C rs3813929 Assay ID: C_27488117_10 from Applied Biosystems (Foster City, CA, USA).

This article is protected by copyright. All rights reserved. 


\section{Statistical analysis}

Demographic characteristics of patient details were expressed as mean \pm standard deviation. HardyWeinberg equilibrium was tested on genotype frequencies. Chi-square test and Fisher's exact test were used to study the association between genotypes and categories of response to risperidone. Kruskal-Wallis test was used to study the association between the genotypes and $\Delta$ PANSS. For bimodal categorical variable, Mann- Whitney U test was used to analyse reduction in PANSS scores between genotypes. All statistical analyses were done with Graph Pad Instat version 3.06.

\section{RESULTS}

A total of $n=320$ patients with schizophrenia were included for the genotype- phenotype analysis. Among the 320 patients, 109 patients were recruited with prospective assessment and 211 patients were recruited in cross-sectional study group. The PANSS score of prospective study group participants was $91.47 \pm 17.71$ (mean $\pm \mathrm{SD}$ ) at baseline and after four weeks of risperidone treatment, the PANSS score was $57.96 \pm 20.49$ (mean \pm SD). Categorically, 84 patients were responders $(20 \%$ reduction on PANSS score) and others 25 patients were non responders. Among the 211 crosssectional study group participants, 154 were responders and 57 were non-responders to risperidone therapy on CGI-I score. All the responders and non-responder's demographic details were given in Table. I.

Genotypic distributions were in Hardy-Weinberg equilibrium for the DRD2 Taq1A $\left(\mathrm{n}=320, \chi^{2}=0.32\right.$, $\mathrm{DF}=1, \mathrm{p}=0.5)$, the HTR2A $\operatorname{rs} 6311(\mathrm{n}=320, \chi 2=1.3, \mathrm{DF}=1, \mathrm{p}=0.2), \operatorname{HTR} 2 A \operatorname{rs} 6313\left(\mathrm{n}=320, \chi^{2}=1.34\right.$, $\mathrm{DF}=1, \mathrm{p}=0.2)$ and the HTR2C $\mathrm{rs} 3813929$ in female subjects $\left(\mathrm{n}=132, \chi^{2}=1.4, \mathrm{DF}=1, \mathrm{p}=0.2\right)$ since this gene is located on X chromosome. During the genotyping of DRD2 -141 C Ins/Del polymorphism, ten samples were not amplified and were excluded. Due to the low frequency of Del allele, the Del/Del subjects $(n=5)$ were combined with Ins/Del genotype to study the association with antipsychotic response.

This article is protected by copyright. All rights reserved. 
No significant association was detected between risperidone response (categorical definition) and DRD2, HTR2A and HTR2C genes polymorphisms (Table. II, IV and V). Similarly, no significant association was detected between the level of response based on the level of reduction of the PANSS score and $D R D 2, H T R 2 A$ and $H T R 2 C$ genes polymorphisms (Table. III). In post-hoc exploratory analyses, no association was detected between the improvement of positive and negative symptoms and general psychopathology sub scores of PANSS score in relation with candidate genes polymorphisms. (Supplementary Table. I).

\section{DISCUSSION}

In the present study, using a prospective assessment of symptom evaluation and using two definitions of response, as well as using CGI-I score response assessment in cross-sectional study group, we have examined the role of the associations of DRD2 (rs1799732, rs1800497), HTR2A (rs6311, rs6313) and $H T R 2 C$ (rs3813929) gene polymorphisms with antipsychotic response among South Indian patients with SCZ. The present study did not find significant influence of the studied polymorphisms on treatment response to risperidone.

Allele frequencies of the $D R D 2$ and $H T R 2 A$ polymorphisms in the present study were consistent with those reported in other studies of Indian populations. Indeed, with regard to DRD2 Taq1A polymorphism, in our sample, G allele frequency (0.69) was consistent with those reported by Vijayan et al (0.69) in South Indian populations and another study by Kaur et al (0.68) in North Indian populations $(50,51)$. For DRD2 $-141 \mathrm{C}$ Ins/Del polymorphism the Ins allele frequency (0.77) could not be compared to other South Indian population with SCZ but consistent with allele frequency of South Indian alcohol dependant patients (0.77) and controls (0.65) [54]. Similarly, another study by Sujitha et al reported the allele frequencies of $H T R 2 A$ gene polymorphisms $-1438 \mathrm{~A}<\mathrm{G}$ (G-0.56; A0.44), and T102C (C-0.58; T-0.42) in patients with SCZ from South Indian populations [41] which is consistent with the present study and also consistent with another recent study by Kaur et al in which $-1438 \mathrm{~A}<\mathrm{G}(\mathrm{G}-0.59 ; \mathrm{A}-0.41)$, and T102C (C-0.56; T-0.44) were reported in patients with SCZ from

This article is protected by copyright. All rights reserved. 
North Indian populations [51]. To the best of our knowledge no data have been reported on HTR2C 759 C $>$ T polymorphism frequency in Indian populations.

Previous studies, two from Japanese, three from Caucasians, one each from Chinese, African American, and Korean populations have found an association between DRD2 Taq1A polymorphism and antipsychotic response $[18,19,31,34,55-58]$. However, present study results are consistent with many other studies that did not find an association between these genetic polymorphisms and treatment response to antipsychotics in other ethnic groups [12,13,32,47,59]. In particular, DRD2 Taq1A and HTR2A (-1438A $>$ G;T102C) polymorphisms results are consistent with previous association studies from Indian populations [50,51]. With regard to the DRD2 -141 Ins/Del polymorphism, present study results did not find an association with antipsychotic response and results are consistent with many of the previous studies $[19,31,32,34,35,59,60]$, with exception of few studies in Chinese, Caucasians and African Americans in whom they have reported an association between DRD2 -141 C Ins/Del polymorphism and antipsychotic response [12,61,62]. In the present study $H T R 2 A$ gene $-1438 \mathrm{~A} / \mathrm{G}$ polymorphism results are consistent with reported previous studies in Japanese, Dutch, and Caucasian populations $[31,32,39]$ and not consistent with a few studies such as studies in Caucasians, Algerian, American and Chinese population in whom they have reported an association $[35,36,38,63]$. Similarly, HTR2A T102C polymorphism results are consistent with many previous studies [25-31,33,34] and not consistent with few studies from Chinese, American, Caucasians, African American, and Korean populations in whom they have reported an association with antipsychotic response $[23,36,46,64,65]$. So far very few studies have investigated the role of HTR2C-759 C/T polymorphism in association with antipsychotic response. In the present study, HTR2C-759 C/T polymorphism did not show significant association with antipsychotic response. Present study findings are consistent with previous study by Ikeda et al in the Japanese population [34] and inconsistent with Reynolds et al who have reported a negative symptom response in the Chinese population [47].

This article is protected by copyright. All rights reserved. 
To the best of our knowledge our study is the first to assess these genetic associations in a large sample of South Indian population with the strengths of ethnic homogeneity, treatment homogeneity with the same atypical antipsychotic tested (risperidone) and definitive response criteria with prospective and cross-sectional assessment. However, previous association studies were reported with use of typical antipsychotics (chlorpromazine, haloperidol, bromperidol, fluphenazine, flupentixol), atypical antipsychotics (clozapine, olanzapine, aripiprazole, nemonapride, amisulpride, sulpride), few studies with mixed medications (typical and atypical) and only six studies have reported with risperidone therapy.

Our results deserve several comments with regard to potential weaknesses. First, short term evaluation of response (only four weeks of treatment may be too short to capture the sufficient variance in primary outcome measure. Of note, Kaur et al 2017 also detected no association between the DRD2 Taq1A and HTR2A (-1438A>G; T102 C) polymorphisms in association with treatment response to risperidone after 12 weeks of treatment in North Indian populations. Second, in the present study, categorical outcome criteria may appear arbitrary (20\% improvement) and outcome was also studied using a continuous definition for the response. However, previous studies have used various response assessment scales with different cut off values and treatment durations to detect the association between genetic polymorphisms and antipsychotic response.

In conclusion, the results obtained from the present study are in line with recent studies by Kaur et al and Vijayan et al to suggest DRD2 (rs1799732, rs1800497), HTR2A (rs6311, rs6313) and HTR2C (rs3813929) genetic polymorphisms are not associated with antipsychotic response. DRD2, HTR2A and $H T R 2 C$ are the important genes involved in the pharmacodynamics of risperidone and several studies have showed the importance of these genes in antipsychotic response. However, recent evidences indicate the role of epigenetic mechanisms in antipsychotic response. A study by Shi et al (2017) showed that methylation status of CYP3A4 gene has a significant role in response to risperidone therapy. Few studies have also suggested the association of gene expression levels from peripheral blood with antipsychotic response. However, no studies have been conducted to study the methylation Further studies are required to investigate the methylation pattern of promotor regions or 
gene regulatory regions for $D R D 2, H T R 2 A, H T R 2 C$ genes and their expression pattern in association with antipsychotic response.

\section{ACKNOWLEDGEMENT}

The study was supported by Jawaharlal Institute of Postgraduate Medical Education and Research (JIPMER) Intramural Research Grant (Grant No. JIP/Res/Intra-PhD/01/2014) and Indo-French Centre for the Promotion of Advanced Research (IFCPAR/ CEFIPRA) for promoting the collaboration (Grant No. IFC/4098/RCF2016/853) between JIPMER and University of Sorbonne universities, Paris, France.

\section{CONFLICT OF INTEREST}

Authors declared no conflicts of interest.

\section{REFERENCES}

[1] Seeman P. Atypical antipsychotics: mechanism of action. Can. J. Psychiatry Rev. 2002;47:27-38.

[2] Richtand N.M., Welge J.A., Logue A.D., Keck P.E., Strakowski S.M., McNamara R.K. Role of serotonin and dopamine receptor binding in antipsychotic efficacy. Prog. Brain Res. 2008;172:155175.

[3] Simonsen E., Friis S., Opjordsmoen S., Mortensen E.L., Haahr U., Melle I. et al. Early identification of non-remission in first-episode psychosis in a two-year outcome study. Acta Psychiatr. Scand. 2010;122:375-383.

[4] Chung Y.-C., Cui Y., Kim M.-G., Kim Y.-J., Lee K.-H., Chae S.-W. Early predictors of a clinical response at 8 weeks in patients with first-episode psychosis treated with paliperidone ER. J. Psychopharmacol. Oxf. Engl. 2016;30:810-818.

[5] Malhotra A.K. Candidate gene studies of antipsychotic drug efficacy and drug-induced weight gain. Neurotox. Res. 2004;6:51-56.

[6] Arranz M.J., Munro J.C. Toward understanding genetic risk for differential antipsychotic response in individuals with schizophrenia. Expert Rev. Clin. Pharmacol. 2011;4:389-405.

This article is protected by copyright. All rights reserved. 
[7] Blanc O., Brousse G., Meary A., Leboyer M., Llorca P.-M. Pharmacogenetic of response efficacy to antipsychotics in schizophrenia: pharmacodynamic aspects. Review and implications for clinical research. Fundam. Clin. Pharmacol. 2010;24:139-160.

[8] Reynolds G.P., McGowan O.O., Dalton C.F. Pharmacogenomics in psychiatry: the relevance of receptor and transporter polymorphisms. Br. J. Clin. Pharmacol. 2014;77:654-672.

[9] Arranz M.J., Gallego C., Salazar J., Arias B. Pharmacogenetic studies of drug response in schizophrenia. Expert Rev. Precis. Med. Drug Dev. 2016;1:79-91.

[10] Arinami T., Gao M., Hamaguchi H., Toru M. A functional polymorphism in the promoter region of the dopamine D2 receptor gene is associated with schizophrenia. Hum. Mol. Genet. 1997;6:577-582.

[11] Pohjalainen T., Rinne J.O., Någren K., Lehikoinen P., Anttila K., Syvälahti E.K. et al. The A1 allele of the human D2 dopamine receptor gene predicts low D2 receptor availability in healthy volunteers. Mol. Psychiatry. 1998;3:256-260.

[12] Wu S., Xing Q., Gao R., Li X., Gu N., Feng G. et al. Response to chlorpromazine treatment may be associated with polymorphisms of the DRD2 gene in Chinese schizophrenic patients. Neurosci. Lett. 2005;376:1-4.

[13] Suzuki A., Kondo T., Mihara K., Yasui-Furukori N., Otani K., Furukori H. et al. Association between TaqI A dopamine D2 receptor polymorphism and therapeutic response to bromperidol: a preliminary report. Eur. Arch. Psychiatry Clin. Neurosci. 2001;251:57-59.

[14] Zhang J.-P., Lencz T., Malhotra A.K. Dopamine D2 receptor genetic variation and clinical response to antipsychotic drug treatment: A meta-analysis. Am. J. Psychiatry. 2010;167:763-772.

[15] Zhang J.-P., Malhotra A.K. Pharmacogenetics and Antipsychotics: Therapeutic Efficacy and Side Effects Prediction. Expert Opin. Drug Metab. Toxicol. 2011;7:9-37.

[16] Huang E., Maciukiewicz M., Zai C.C., Tiwari A.K., Li J., Potkin S.G. et al. Preliminary evidence for association of genome-wide significant DRD2 schizophrenia risk variant with clozapine response. Pharmacogenomics. 2016;17:103-109.

[17] Kang S.-G., Na K.-S., Lee H.-J., Chee I.-S., Lee K., Lee J. DRD2 genotypic and haplotype variation is associated with improvements in negative symptoms after 6 weeks' amisulpride treatment. J. Clin. Psychopharmacol. 2015;35:158-162.

[18] Suzuki A., Mihara K., Kondo T., Tanaka O., Nagashima U., Otani K. et al. The relationship between dopamine D2 receptor polymorphism at the Taq1 A locus and therapeutic response to nemonapride, a selective dopamine antagonist, in schizophrenic patients. Pharmacogenetics. 2000;10:335-341.

[19] Hwang R., Shinkai T., De Luca V., Müller D.J., Ni X., Macciardi F. et al. Association study of 12 polymorphisms spanning the dopamine $\mathrm{D}(2)$ receptor gene and clozapine treatment response in two treatment refractory/intolerant populations. Psychopharmacology (Berl). 2005;181:179-187.

[20] Ruble C.L., Smith R.M., Calley J., Munsie L., Airey D.C., Gao Y. et al. Genomic structure and expression of the human serotonin 2A receptor gene (HTR2A) locus: identification of novel HTR2A and antisense (HTR2A-AS1) exons. BMC Genet [Internet]. $2016 ; 17$.

This article is protected by copyright. All rights reserved. 
Available from: http://www.ncbi.nlm.nih.gov/pmc/articles/PMC4702415/

[21] Parsons M.J., D’Souza U.M., Arranz M.-J., Kerwin R.W., Makoff A.J. The -1438A/G polymorphism in the 5-hydroxytryptamine type $2 \mathrm{~A}$ receptor gene affects promoter activity. Bio. Psychiatry. 2004;56:406-410.

[22] Polesskaya O.O., Aston C., Sokolov B.P. Allele C-specific methylation of the 5-HT2A receptor gene: evidence for correlation with its expression and expression of DNA methylase DNMT1. J. Neurosci. Res. 2006;83:362-373.

[23] Lane H.-Y., Chang Y.-C., Chiu C.-C., Chen M.-L., Hsieh M.-H., Chang W.-H. Association of risperidone treatment response with a polymorphism in the 5-HT(2A) receptor gene. Am. J. Psychiatry. 2002;159:1593-1595.

[24] Ellingrod V.L., Perry P.J., Lund B.C., Bever-Stille K., Fleming F., Holman T.L. et al. 5HT2A and $5 \mathrm{HT} 2 \mathrm{C}$ receptor polymorphisms and predicting clinical response to olanzapine in schizophrenia. J. Clin. Psychopharmacol. 2002;22:622-624.

[25] Masellis M., Paterson A.D., Badri F., Lieberman J.A., Meltzer H.Y., Cavazzoni P. et al. Genetic variation of 5-HT2A receptor and response to clozapine. Lancet Lond. Engl. 1995;346:1108.

[26] Nöthen M.M., Rietschel M., Erdmann J., Oberländer H., Möller H.J., Nober D. et al. Genetic variation of the 5-HT2A receptor and response to clozapine. Lancet Lond. Engl. 1995;346:908-909.

[27] Malhotra A.K., Goldman D., Ozaki N., Breier A., Buchanan R., Pickar D. Lack of association between polymorphisms in the 5-HT2A receptor gene and the antipsychotic response to clozapine. Am. J. Psychiatry. 1996;153:1092-1094.

[28] Masellis M., Basile V., Meltzer H.Y., Lieberman J.A., Sevy S., Macciardi F.M. et al. Serotonin subtype 2 receptor genes and clinical response to clozapine in schizophrenia patients. Neuropsychopharmacol Off Publ. Am. Coll. Neuropsychopharmacol. 1998;19:123-132.

[29] Joober R., Benkelfat C., Brisebois K., Toulouse A., Turecki G., Lal S. et al. T102C polymorphism in the 5HT2A gene and schizophrenia: relation to phenotype and drug response variability. J. Psychiatry Neurosci. 1999;24:141-146.

[30] Lin C.H., Tsai S.J., Yu Y.W., Song H.L., Tu P.C., Sim C.B. et al. No evidence for association of serotonin-2A receptor variant (102T/C) with schizophrenia or clozapine response in a Chinese population. Neuroreport. 1999;10:57-60.

[31] Yamanouchi Y., Iwata N., Suzuki T., Kitajima T., Ikeda M., Ozaki N. Effect of DRD2, 5HT2A, and COMT genes on antipsychotic response to risperidone. Pharmacogenomics J. 2003;3:356-361.

[32] Vehof J., Burger H., Wilffert B., Al Hadithy A., Alizadeh B.Z., Snieder H. et al. Clinical response to antipsychotic drug treatment: association study of polymorphisms in six candidate genes. Eur. Neuropsychopharmacol. J. Eur. Coll. Neuropsychopharmacol. 2012;22:625-631.

[33] Jönsson E., Nöthen M.M., Bunzel R., Propping P., Sedvall G. 5HT 2a receptor T102C polymorphism and schizophrenia. Lancet Lond. Engl. 1996;347:1831.

This article is protected by copyright. All rights reserved. 
[34] Ikeda M., Yamanouchi Y., Kinoshita Y., Kitajima T., Yoshimura R., Hashimoto S. et al. Variants of dopamine and serotonin candidate genes as predictors of response to risperidone treatment in first-episode schizophrenia. Pharmacogenomics. 2008;9:1437-1443.

[35] Arranz M.J., Munro J., Owen M.J., Spurlock G., Sham P.C., Zhao J. et al. Evidence for association between polymorphisms in the promoter and coding regions of the 5-HT2A receptor gene and response to clozapine. Mol. Psychiatry. 1998;3:61-66.

[36] Chen S.-F., Shen Y.-C., Chen C.-H. HTR2A A-1438G/T102C polymorphisms predict negative symptoms performance upon aripiprazole treatment in schizophrenic patients. Psychopharmacology (Berl). 2009 205:285-292.

[37] Benmessaoud D., Hamdani N., Boni C., Ramoz N., Hamon M., Kacha F. et al. Excess of transmission of the $\mathrm{G}$ allele of the $-1438 \mathrm{~A} / \mathrm{G}$ polymorphism of the 5 -HT2A receptor gene in patients with schizophrenia responsive to antipsychotics. BMC Psychiatry. 2008;8:40.

[38] Ellingrod V.L., Lund B.C., Miller D., Fleming F., Perry P., Holman T.L. et al. 5-HT2A receptor promoter polymorphism, $-1438 \mathrm{G} / \mathrm{A}$ and negative symptom response to olanzapine in schizophrenia. Psychopharmacol Bull. 2003;37:109-112.

[39] Hamdani N., Bonnière M., Adès J., Hamon M., Boni C., Gorwood P. Negative symptoms of schizophrenia could explain discrepant data on the association between the 5-HT2A receptor gene and response to antipsychotics. Neurosci. Lett. 2005;377:69-74.

[40] Araga U.S., Narasu M.L. Association between the 102T/C polymorphism of serotonin-2A receptor gene and schizophrenia among south Indians. Mol. Psychiatry. 2002;7:540-541.

[41] Sujitha S.P., Nair A., Banerjee M., Lakshmanan S., Harshavaradhan S., Gunasekaran S. et al. 5Hydroxytryptamine (serotonin) 2A receptor gene polymorphism is associated with schizophrenia. Indian J. Med. Res. 2014;140:736-743.

[42] Sodhi M.S., Arranz M.J., Curtis D., Ball D.M., Sham P., Roberts G.W. et al. Association between clozapine response and allelic variation in the 5-HT2C receptor gene. Neuroreport. 1995;7:169-172.

[43] Rietschel M., Naber D., Fimmers R., Möller H.J., Propping P., Nöthen M.M. Efficacy and sideeffects of clozapine not associated with variation in the 5-HT2C receptor. Neuroreport. 1997;8:19992003.

[44] Masellis M., Basile V., Meltzer H.Y., Lieberman J.A., Sevy S., Macciardi F.M. et al. Serotonin subtype 2 receptor genes and clinical response to clozapine in schizophrenia patients. Neuropsychopharmacol Off Publ Am Coll Neuropsychopharmacol. 1998;19:123-132.

[45] Schumacher J., Schulze T.G., Wienker T.F., Rietschel M., Nöthen M.M. Pharmacogenetics of clozapine response. The Lancet. 2000;356:506-507.

[46] Ellingrod V.L., Perry P.J., Lund B.C., Bever-Stille K., Fleming F., Holman T.L. et al. 5HT2A and 5HT2C receptor polymorphisms and predicting clinical response to olanzapine in schizophrenia. J. Clin. Psychopharmacol. 2002;22:622-624.

[47] Reynolds G.P., Yao Z., Zhang X., Sun J., Zhang Z. Pharmacogenetics of treatment in firstepisode schizophrenia: D3 and 5-HT2C receptor polymorphisms separately associate with positive

This article is protected by copyright. All rights reserved. 
and negative symptom response. Eur. Neuropsychopharmacol. J. Eur. Coll. Neuropsychopharmacol. 2005;15:143-151.

[48] Malhotra A.K. Goldman D., Ozaki N., Rooney W., Clifton A., Buchanan R.W. et al. Clozapine response and the 5HT2C Cys23Ser polymorphism. Neuroreport. 1996 Sep 2;7(13):2100-2102.

[49] Polesskaya O.O., Sokolov B.P. Differential expression of the "C" and "T" alleles of the 5-HT2A receptor gene in the temporal cortex of normal individuals and schizophrenics. J. Neurosci. Res. 2002;67:812-822.

[50] Vijayan N.N., Bhaskaran S., Koshy L.V., Natarajan C., Srinivas L., Nair C.M. et al. Association of dopamine receptor polymorphisms with schizophrenia and antipsychotic response in a South Indian population. Behav. Brain Funct. BBF. 2007;3:34.

[51] Kaur G., Gupta D., Chavan B.S., Sinhmar V., Prasad R., Tripathi A. et al. Identification of genetic correlates of response to Risperidone: Findings of a multicentric schizophrenia study from India. Asian J. Psychiatry. 2017;29:174-182.

[52] Busner J., Targum S.D. The Clinical Global Impressions Scale. Psychiatry Edgmont. 2007;4:2837.

[53] Haas M., Unis A.S., Armenteros J., Copenhaver M.D., Quiroz J.A., Kushner S.F. A 6-week, randomized, double-blind, placebo-controlled study of the efficacy and safety of risperidone in adolescents with schizophrenia. J. Child Adolesc. Psychopharmacol. 2009;19:611-621.

[54] Prasad P., Ambekar A., Vaswani M. Case-control association analysis of Dopamine receptor polymorphisms in alcohol dependence: a pilot study in Indian males. BMC Res. Notes. 2013;6:418.

[55] Schäfer M., Rujescu D., Giegling I., Guntermann A., Erfurth A., Bondy B. et al. Association of short-term response to haloperidol treatment with a polymorphism in the dopamine $\mathrm{D}(2)$ receptor gene. Am. J. Psychiatry. 2001;158:802-804.

[56] Dahmen N., Müller M.J., Germeyer S., Rujescu D., Anghelescu I., Hiemke C. et al. Genetic polymorphisms of the dopamine D2 and D3 receptor and neuroleptic drug effects in schizophrenic patients. Schizophr. Res. 2001;49:223-225.

[57] Shen Y.-C., Chen S.-F., Chen C.-H., Lin C.C.H., Chen S.-J., Chen Y.-J. et al. Effects of DRD2/ANKK1 gene variations and clinical factors on aripiprazole efficacy in schizophrenic patients. J. Psychiatr. Res. 2009;43:600-606.

[58] Kwon J.S., Kim E., Kang D.-H., Choi J.S., Yu K.-S., Jang I.-J. et al. Taq1A polymorphism in the dopamine D2 receptor gene as a predictor of clinical response to aripiprazole. Eur. Neuropsychopharmacol. J. Eur. Coll. Neuropsychopharmacol. 2008;18:897-907.

[59] Xing Q., Qian X., Li H., Wong S., Wu S., Feng G. et al. The relationship between the therapeutic response to risperidone and the dopamine D2 receptor polymorphism in Chinese schizophrenia patients. Int. J. Neuropsychopharmacol. 2007;10:631-637.

[60] Shen Y.-C., Chen S.-F., Chen C.-H., Lin C.C.H., Chen S.-J., Chen Y.-J. et al. Effects of DRD2/ANKK1 gene variations and clinical factors on aripiprazole efficacy in schizophrenic patients. J. Psychiatr. Res. 2009;43:600-606.

This article is protected by copyright. All rights reserved. 
[61] Malhotra A., Buchanan R., Breier A., Picken L., Pickar D., Goldman D. Allelic variation in the promoter region of the dopamine D2 receptor gene influences the antipsychotic response to clozapine. Am. J. Med. Genet. B Neuropsychiatr. Genet. 1998;81:477-478.

[62] Lencz T., Robinson D.G., Xu K., Ekholm J., Sevy S., Gunduz-Bruce H. et al. DRD2 promoter region variation as a predictor of sustained response to antipsychotic medication in first-episode schizophrenia patients. Am. J. Psychiatry. 2006;163:529-531.

[63] Benmessaoud D., Hamdani N., Boni C., Ramoz N., Hamon M., Kacha F. et al. Excess of transmission of the $\mathrm{G}$ allele of the $-1438 \mathrm{~A} / \mathrm{G}$ polymorphism of the 5-HT2A receptor gene in patients with schizophrenia responsive to antipsychotics. BMC Psychiatry. 2008;8:40.

[64] Nimgaonkar V.L., Zhang X.R. Brar J.S., DeLeo M., Ganguli R. 5-HT2 receptor gene locus: association with schizophrenia or treatment response not detected. Psychiatr. Genet. 1996;6:23-27.

[65] Kim B., Choi E.Y., Kim C.Y., Song K., Joo Y.H. Could HTR2A T102C and DRD3 Ser9Gly predict clinical improvement in patients with acutely exacerbated schizophrenia? Results from treatment responses to risperidone in a naturalistic setting. Hum. Psychopharmacol. 2008;23:61-67.

This article is protected by copyright. All rights reserved. 


\section{Tables}

Table. I Demographic characteristic of responders and non-responders

\begin{tabular}{|c|c|c|c|}
\hline \multicolumn{4}{|c|}{ Prospective study group } \\
\hline Parameter & Responders (n=84) & Non-responders (n=25) & p value \\
\hline Age (Years) & $29 \pm 8.6$ & $35 \pm 10.3$ & 0.002 \\
\hline Height (cm) & $167.73 \pm 9.74$ & $152.73 \pm 10.14$ & 0.0001 \\
\hline Weight (kg) & $61.65 \pm 12.6$ & $53.27 \pm 12.56$ & 0.007 \\
\hline $\begin{array}{c}\text { Risperidone dose (mg/day) } \\
\text { Median (IQR) }\end{array}$ & $4(4-6)$ & $4(4-6)$ & \\
\hline \multicolumn{4}{|c|}{ Cross-sectional study group } \\
\hline Agesponders (n=154) & Non-responders (n=57) & p value \\
\hline Height (cm) & $36.5 \pm 10.2$ & $33.8 \pm 10.5$ & 0.09 \\
\hline Weight (kg) & $160.6 \pm 9.3$ & $153.1 \pm 9.2$ & 0.001 \\
\hline $\begin{array}{c}\text { Risperidone dose (mg/day) } \\
\text { Median (IQR) }\end{array}$ & $60.6 \pm 12$ & $58.95 \pm 11.9$ & 0.3 \\
\hline
\end{tabular}

This article is protected by copyright. All rights reserved. 
Table. II Genotype association tests between $D R D 2, H T R 2 A$ and HTR2C genes polymorphisms and antipsychotic response to risperidone in the prospective and cross-sectional samples pooled (categorical definition of responders and non-responders)

\begin{tabular}{|c|c|c|c|c|}
\hline $\begin{array}{c}\text { DRD2 -141 C Ins/Del } \\
\text { (rs1799732) }\end{array}$ & Ins/Ins (n=177) & $\begin{array}{c}\text { Ins/Del +Del/Del } \\
\quad(n=133)\end{array}$ & $\begin{array}{c}\text { Odds ratio } \\
(95 \% \mathrm{CI})\end{array}$ & p value \\
\hline Responders & 127 & 104 & \multirow[t]{2}{*}{$0.70(0.4-1.2)$} & \multirow[t]{2}{*}{0.2} \\
\hline Non responders & 50 & 29 & & \\
\hline \multicolumn{5}{|c|}{ Fisher's exact test $\mathrm{p}<0.05$ considered as significant } \\
\hline $\begin{array}{c}\text { DRD2 Taq1A } \\
\text { (rs1800497) }\end{array}$ & $\mathbf{A A}(\mathbf{n}=35)$ & AG $(n=132)$ & GG $(n=153)$ & p value \\
\hline Responders & 24 & 104 & 110 & \multirow[t]{2}{*}{0.2} \\
\hline Non responders & 11 & 28 & 43 & \\
\hline \multicolumn{5}{|c|}{$\chi^{2}=2.4, \mathrm{DF}=2, \mathrm{p}<0.05$ considered as significant } \\
\hline $\begin{array}{c}\text { HTR2A }-1438 \text { A }>\text { G } \\
(\text { rs6311) }\end{array}$ & AA $(n=39)$ & AG $(n=164)$ & GG $(n=117)$ & p value \\
\hline Responders & 31 & 126 & 81 & \multirow[t]{2}{*}{0.2} \\
\hline Non responders & 8 & 38 & 36 & \\
\hline \multicolumn{5}{|c|}{$\chi^{2}=2.7, \mathrm{DF}=2, \mathrm{p}<0.05$ considered as significant } \\
\hline $\begin{array}{c}\text { HTR2A T102C } \\
\text { (rs6313) }\end{array}$ & $\mathrm{CC}(\mathrm{n}=115)$ & CT $(n=165)$ & TT $(n=40)$ & p value \\
\hline Responders & 80 & 124 & 34 & \multirow[t]{2}{*}{0.1} \\
\hline Non responders & 35 & 41 & 6 & \\
\hline \multicolumn{5}{|c|}{$\chi^{2}=3.8, \mathrm{DF}=2, \mathrm{p}<0.05$ considered as significant } \\
\hline $\begin{array}{c}\text { HTR2C }-759 \mathrm{C}>\mathrm{T} \\
(\text { rs3813929) } \\
\text { Females } \\
\end{array}$ & $\mathrm{CC}(\mathrm{n}=65)$ & CT +TT $(n=67)$ & $\begin{array}{c}\text { Odds ratio } \\
(95 \% \mathrm{CI})\end{array}$ & p value \\
\hline Responders & 50 & 48 & \multirow[t]{2}{*}{$1.3(0.6-2.8)$} & \multirow[t]{2}{*}{0.5} \\
\hline Non responders & 15 & 19 & & \\
\hline Males & $C(n=120)$ & $T(n=66)$ & $\begin{array}{l}\text { Odds ratio } \\
(95 \% \mathrm{CI})\end{array}$ & p value \\
\hline Responders & 91 & 47 & \multirow[t]{2}{*}{$1.2(0.6-2.4)$} & \multirow[t]{2}{*}{0.4} \\
\hline Non responders & 29 & 19 & & \\
\hline \multicolumn{5}{|c|}{ Fisher's exact test $\mathrm{p}<0.05$ considered as significant } \\
\hline
\end{tabular}

This article is protected by copyright. All rights reserved. 
Table. III Genotype association tests between $D R D 2, H T R 2 A$ and HTR2C genes polymorphisms and reduction in PANSS score

\begin{tabular}{|c|c|c|c|c|c|}
\hline Gene & SNP (rsID) & \multicolumn{3}{|c|}{ PANSS score difference between the genotypes } & \multirow[b]{2}{*}{ p value } \\
\hline \multirow[t]{4}{*}{ DRD2 } & -141 C Ins/Del (rs1799732) & Ins/Ins $(n=54)$ & Ins/Del+ D & Del $(n=45)$ & \\
\hline & $\triangle$ PANSS & $33.29 \pm 21.03$ & \multicolumn{2}{|c|}{$34.1 \pm 19.3$} & 0.8 \\
\hline & Taq1A (rs1800497) & $\mathbf{A A}(\mathbf{n}=\mathbf{1 0})$ & AG $(\mathrm{N}=49)$ & GG $(\mathrm{N}=\mathbf{5 0})$ & p value \\
\hline & $\Delta$ PANSS & $26.8 \pm 21.7$ & $36.59 \pm 20.6$ & $31.82 \pm 18.6$ & 0.3 \\
\hline \multirow{4}{*}{ HTR2A } & $-1438 \mathrm{~A}>\mathrm{G}(\mathrm{rs} 6311)$ & $\mathbf{A A}(\mathbf{n}=17)$ & $\mathbf{A G}(\mathbf{n}=\mathbf{5 5})$ & GG(n=37) & p value \\
\hline & $\triangle$ PANSS & $25.94 \pm 18.31$ & $36.72 \pm 19.5$ & $32.18 \pm 20.6$ & 0.12 \\
\hline & T102C (rs6313) & $\mathrm{CC}(\mathrm{n}=35)$ & CT $(\mathbf{n}=58)$ & TT $(n=16)$ & p value \\
\hline & $\triangle$ PANSS & $32.62 \pm 20.6$ & $35.8 \pm 19.8$ & $27.06 \pm 18.3$ & 0.2 \\
\hline \multirow{6}{*}{$\mathrm{HTR} 2 \mathrm{C}$} & Females & & & & \\
\hline & -759 C>T (rs3813929) & $\mathrm{CC}(\mathrm{n}=22)$ & CT $(n=24)$ & TT $(n=3)$ & p value \\
\hline & $\Delta$ PANSS & $36.5 \pm 21.83$ & $31.75 \pm 18.23$ & $34.33 \pm 12.6$ & 0.6 \\
\hline & Males & & & & \\
\hline & $-759 \mathrm{C}>\mathrm{T}(\mathrm{rs3813929})$ & $C(n=37)$ & \multicolumn{2}{|c|}{$T(n=23)$} & p value \\
\hline & $\Delta$ PANSS & $35.10 \pm 21.05$ & \multicolumn{2}{|c|}{$29.78 \pm 19.35$} & 0.4 \\
\hline
\end{tabular}

All values expressed as Mean \pm SD, Kruskal-Wallis test and Mann-Whitney U test p-value $<0.05$ considered as significant

This article is protected by copyright. All rights reserved. 
Table. IV Genotype association tests between $D R D 2, H T R 2 A$ and $H T R 2 C$ genes polymorphism and antipsychotic response to risperidone in prospective study group.

\begin{tabular}{|c|c|c|c|c|}
\hline $\begin{array}{c}\text { DRD2 -141 C } \\
\text { Ins/Del }\end{array}$ & Ins/Ins $(n=54)$ & $\begin{array}{c}\text { Ins/Del +Del/Del } \\
(n=45)\end{array}$ & Odds ratio $(95 \% \mathrm{CI})$ & p value \\
\hline Responders & 41 & 36 & \multirow[t]{2}{*}{$0.78(0.3-2.0)$} & \multirow[t]{2}{*}{0.8} \\
\hline Non responders & 13 & 9 & & \\
\hline \multicolumn{5}{|c|}{ Fisher's exact test $\mathrm{p}<0.05$ considered as significant } \\
\hline DRD2 Taq1A & AA $(n=10)$ & AG $(n=49)$ & GG $(n=50)$ & p value \\
\hline Responders & 6 & 40 & 38 & \multirow[t]{2}{*}{0.3} \\
\hline Non responders & 4 & 9 & 12 & \\
\hline \multicolumn{5}{|c|}{$\chi^{2}=2.25, \mathrm{DF}=2, \mathrm{p}<0.05$ considered as significant } \\
\hline HTR2A -1438 A>G & $\mathbf{A A}(n=17)$ & AG $(n=55)$ & GG $(n=37)$ & p value \\
\hline Responders & 12 & 46 & 26 & \multirow[t]{2}{*}{0.2} \\
\hline Non responders & 5 & 9 & 11 & \\
\hline \multicolumn{5}{|c|}{$\chi^{2}=2.71, \mathrm{DF}=2, \mathrm{p}<0.05$ considered as significant } \\
\hline HTR2A T102C & $C C(n=35)$ & CT $(n=58)$ & TT $(n=16)$ & p value \\
\hline Responders & 25 & 47 & 12 & \multirow[t]{2}{*}{0.5} \\
\hline Non responders & 10 & 11 & 4 & \\
\hline \multicolumn{5}{|c|}{$\chi^{2}=1.18, \mathrm{DF}=2, \mathrm{p}<0.05$ considered as significant } \\
\hline $\begin{array}{c}\text { HTR2C -759 C>T } \\
\text { Females }\end{array}$ & $\mathrm{CC}(\mathrm{n}=22)$ & $\begin{array}{c}\text { CT }(\mathbf{n}=24)+T T \\
(n=3)\end{array}$ & Odds ratio $(95 \% \mathrm{CI})$ & p value \\
\hline Responders & 18 & 21 & \multirow[t]{2}{*}{$1.2(0.3-5.2)$} & \multirow[t]{2}{*}{1.0} \\
\hline Non responders & 4 & 6 & & \\
\hline Males & $C(n=37)$ & $T(n=23)$ & Odds ratio $(95 \% \mathrm{CI})$ & p value \\
\hline Responders & 30 & 15 & \multirow[t]{2}{*}{$2.2(0.6-7.5)$} & \multirow[t]{2}{*}{0.2} \\
\hline Non responders & 7 & 8 & & \\
\hline \multicolumn{5}{|c|}{ Fisher's exact test $p<0.05$ considered as significant } \\
\hline
\end{tabular}

This article is protected by copyright. All rights reserved. 
Table. V Genotype association tests between DRD2, HTR2A and HTR2C genes polymorphisms and antipsychotic response to risperidone in cross-sectional study group

\begin{tabular}{|c|c|c|c|c|}
\hline $\begin{array}{c}\text { DRD2 -141 C } \\
\text { Ins/Del }\end{array}$ & $\begin{array}{l}\text { Ins/Ins } \\
(\mathrm{n}=\mathbf{1 2 3})\end{array}$ & $\begin{array}{c}\text { Ins/Del (84) + Del/Del } \\
(n=4)\end{array}$ & Odds ratio $(95 \% \mathrm{CI})$ & p value \\
\hline Responders & 86 & $67+1$ & \multirow[t]{2}{*}{$0.68(0.3-1.2)$} & \multirow[t]{2}{*}{0.2} \\
\hline \multirow[t]{2}{*}{ Non responders } & 37 & $17+3$ & & \\
\hline & \multicolumn{4}{|c|}{ Fisher's exact test $\mathrm{p}<0.05$ considered as significant } \\
\hline DRD2 Taq1A & GG $(n=103)$ & AG $(n=83)$ & AA $(\mathbf{n}=25)$ & p value \\
\hline Responders & 72 & 64 & 18 & \multirow[t]{2}{*}{0.5} \\
\hline \multirow[t]{2}{*}{ Non responders } & 31 & 19 & 7 & \\
\hline & \multicolumn{4}{|c|}{$\chi^{2}=1.2, \mathrm{DF}=2, \mathrm{p}<0.05$ considered as significant } \\
\hline HTR2A -1438 A>G & GG $(\mathbf{n}=\mathbf{8 0})$ & $\mathrm{AG}(109)+\mathrm{AA}(\mathrm{n}=22)$ & Odds ratio $(95 \% \mathrm{CI})$ & p value \\
\hline Responders & 55 & $80+19$ & \multirow[t]{2}{*}{$0.7(0.3-1.3)$} & \multirow[t]{2}{*}{0.3} \\
\hline \multirow[t]{2}{*}{ Non responders } & 25 & $29+3$ & & \\
\hline & \multicolumn{4}{|c|}{ Fisher's exact test, $\mathrm{p}<0.05$ considered as significant } \\
\hline HTR2A T102C & $\mathrm{CC}(\mathbf{n}=\mathbf{8 0})$ & CT $(n=107)+T T(n=24)$ & Odds ratio $(95 \% \mathrm{CI})$ & p value \\
\hline Responders & 55 & $77+22$ & \multirow[t]{2}{*}{$0.7(0.3-1.3)$} & \multirow[t]{2}{*}{0.3} \\
\hline \multirow[t]{2}{*}{ Non responders } & 25 & $30+2$ & & \\
\hline & \multicolumn{4}{|c|}{ Fisher's exact test, $\mathrm{p}<0.05$ considered as significant } \\
\hline $\begin{array}{c}\text { HTR2C }-759 \mathrm{C}>\mathrm{T} \\
\text { Females }\end{array}$ & $\mathrm{CC}(\mathrm{n}=\mathbf{4 3})$ & CT $(n=25)+T T(n=15)$ & Odds ratio $(95 \% \mathrm{CI})$ & p value \\
\hline Responders & 32 & $16+11$ & \multirow[t]{2}{*}{$1.4(0.54-3.6)$} & \multirow[t]{2}{*}{0.6} \\
\hline Non responders & 11 & $9+4$ & & \\
\hline Males & $C(n=83)$ & $T(n=43)$ & Odds ratio $(95 \% \mathrm{CI})$ & p value \\
\hline Responders & 61 & 32 & \multirow[t]{2}{*}{$0.95(0.41-2.21)$} & \multirow[t]{2}{*}{1.0} \\
\hline Non responders & 22 & 11 & & \\
\hline & \multicolumn{4}{|c|}{ Fisher's exact test $p<0.05$ considered as significant } \\
\hline
\end{tabular}

\section{Foot notes}

Table. III

All values expressed as Mean \pm SD, Kruskal-Wallis test and Mann-Whitney U test p-value $<0.05$ considered as significant.

Supplementary Table. I

All values expressed as Mean \pm SD, Kruskal-Wallis test and Mann-Whitney U test p-value $<0.05$ considered as significant.

This article is protected by copyright. All rights reserved. 